\title{
Neviditelná skupina aneb Co s postdoktorandy?
}

\author{
Jiří Mareš \\ Univerzita Karlova v Praze, Lékařská fakulta v Hradci Králové
}

Redakci zasláno 15. 11. 2012 / upravená verze obdržena 11. 1. 2013 / k uveřejnění přijato

11. 1.2013

\begin{abstract}
Abstrakt: Sdělení si klade za cíl: (1) upozornit na situaci, kdy vysoké školy v České republice produkují desítky absolventů doktorského studia ročně a málo se zajímají o jejich další osud; (2) charakterizovat pojem postdoktorand a přiblí̌zit výzkumy, které tuto skupinu vysokoškoláků zkoumají; (3) předložit údaje o absolventech doktorského studia pedagogiky v České republice; (4) diskutovat domácí kontext, který ovlivňuje uplatnění postdoktorandů; (5) shrnout zahraniční poznatky o systematické práci s postdoktorandy. $\mathrm{V}$ první části je charakterizována současná situace $\mathrm{v}$ ČR i v zahraničí. Druhá část příspěvku popisuje výzkumnou sondu o počtech úspěšných absolventů doktorského studia Pedagogika. Třetí část je věnována zamyšlení nad domácím kontextem, který ovlivňuje uplatnění postdoktorandů. Čtvrtá část shrnuje zahraniční zkušenosti se systematickou prací s postdoktorandy. Ukázalo se, že v letech 1999-2011 úspěšně dokončilo doktorské studium v programu Pedagogika v ČR 549 osob. Soustavná práce s postdoktorandy je na třech velkých českých univerzitách (Univerzita Karlova, Masarykova a Palackého) teprve v počátcích. Z uvedeného vyplývá, že v ČR bude třeba pravidelně sledovat, kde postdoktorandi pracují, nakolik se věnují vědecké činnosti a jak vypadá jejich kvalifikační růst. Kromě toho bude třeba (s oporou o zahraniční zkušenost) propracovat systém, který postdoktorandům umožní různými cestami se zdokonalovat ve svých znalostech a dovednostech.
\end{abstract}

Klíčová slova: doktorské studium, pedagogika, postdoktorand, kariéra, pedagogický výzkum

\section{1 Úvod}

Fakulty připravující učitele i Akreditační komise vlády věnují - zejména v posledních letech - velkou pozornost tomu, jak kvalitně probíhá doktorské studium v programu Pedagogika. Kontroluje se koncepce vědecké př́ípravy, personální zajištění tohoto doktorského studia, výzkumná činnost garantujícího pracoviště, kvalita publikační činnosti garantů a školitelů, kvalita publikační činnosti doktorandů i kvalita obhájených disertací. Pod tímto tlakem se postupně zlepšuje př́íprava odborníkủ, kteří by měli po absolvování doktorského studia rozvíjet pedagogiku jako vědu a provádět solidní pedagogický výzkum. 
Pedagogika jako vědní obor má i své blízké obory. Jsou jimi oborové didaktiky. Po letech pochybností, zda jde vủbec o vědecké disciplíny, po dalších letech rozpačitého přešlapování se postupně daří konstituovat i oborové didaktiky jako vědní obory. K tradičním oborovým didaktikám typu matematika, fyzika, hudební výchova, výtvarná výchova, tělesná výchova postupně přibývají další: chemie, dějepis, biologie, český jazyk, cizí jazyky aj. Původně mnohé z nich byly (a na některých fakultách stále ještě jsou) zahrnuty pod doktorské studium Pedagogiky. Toto studium plnilo a plní funkci jakéhosi inkubátoru, než se oborové didaktiky osamostatní. Snahou Akreditační komise vlády (zejména díky I. Stuchlíkové a V. Dvořákové) je, aby se oborové didaktiky staly plnoprávnými a samostatnými vědeckými obory, které budou schopny si vychovávat kvalitní doktorandy.

\section{Dosavadní situace}

S pozorností, která je nyní u nás věnována postgraduálnímu doktorskému studiu obecně (jižtřetírokse postupněkontrolujekvalita všech akreditovaných doktorských studijních programů na všech českých vysokých školách), kontrastuje minimální zájem o to, co se děje s absolventy doktorského studia.

Přehledová studie si klade tyto cíle: (1) upozornit na situaci, kdy vysoké školy v České republice produkují desítky absolventů doktorské studia ročně a jen minimálně se zajímají o jejich další osud; (2) charakterizovat pojem postdoktorand a přiblížit výzkumy, které tuto skupinu vysokoškoláků zkoumají; (3) předložit údaje o absolventech doktorského studia pedagogiky v České republice; (4) diskutovat domácí kontext, který ovlivňuje uplatnění postdoktorandů; (5) shrnout zahraniční poznatky o systematické práci s postdoktorandy.

Jak chápat pojem postdoktorand? Jednotlivé definice postdoktoranda se poněkud liší, ale obvykle se tímto termínem označuje úspěšný absolvent doktorského studia, který získal doktorský titul. Bývá přijat na dobu určitou do instituce na pozici výzkumného pracovníka. Bud' provádí výzkum pod odborným dohledem mentora, a/nebo absolvuje další výcvik ve vědeckých činnostech. V obou případech jde o to, aby získal profesionální výzkumné dovednosti, které jsou potřebné pro odbornou dráhu, kterou si zvolil (modifikovaně podle National Postdoctoral Assocation, 2013). V některých publikacích se ještě dodává, že jeho pobyt je financován z výzkumného grantu nebo z výzkumného kontraktu či výcvikového grantu. 
Existují také definice účelové, vázané na konkrétní typ grantů či konkrétní instituci. Ty předem rezignují na obecnější pojetí. Např. české MŠMT (2011) stanovilo, že postdoktorand je

mladý výzkumník, který se nejdéle do tř́let od úspěšného absolvování příslušného doktorského studijního programu rozhodne pokračovat ve výzkumné kariéře. Jedná se o dočasnou pozici. Postdoktorand nastoupí do výzkumné organizace či vysoké školy, aby tam po omezenou dobu cca 2-3 let pracoval v novém týmu. To mu dává možnost rozšírít si obzory, získat další zkušenosti, dosáhnout výsledků a publikovat je. (MŠMT, 2011)

Podobně australská výzkumná sonda, která byla provedena na University of Western Australia, definovala postdoktoranda časově, v tomto případě, jako jedince, který získal Ph.D. během posledních 6 let (Scaffidiová \& Bermanová, 2011, s. 687).

Pro naše úvahy jsou tyto definice př́liš úzké, nebot' ne všichni absolventi doktorského studia se nakonec stávají profesionálními výzkumníky. Řada z nich působí jako učitelé na vysokých školách, kde je výzkumná činnost jen jednou částí náplně jejich práce, druhou (často dominující) je pedagogická činnost.

Paradoxní je, že v USA a Velké Británii sice vznikly speciální instituce, které pečují o postdoktorandy, pomáhají řešit jejich praktické problémy ${ }^{1}$, ale najdeme jen minimum empirických výzkumủ, které by se hlouběji zabývaly situací doktorandů po skončení studia. Uved'me některé výjimky:

Patři k nim studie Thomsona et al. (2001), která mapovala situaci postdoktorandů v Austrálii. Na tuto studii navázala práce jednoho z členů tohoto týmu - G. S. Åkerlinda (2005). Ten v závěru své práce konstatoval: chybí věcná definice postdoktoranda a jeho postavení na pracovišti, chybí ucelená koncepce, jak s postdoktorandy pracovat, chybí empirická data o tom, jak se využívají jejich získané znalosti a dovednosti. Stoupá nespokojenost postdoktorandů s vlastní pozicí a se svou další perspektivou. Do větších podrobností o reálné situaci u 204 australských postdoktorandů šel jednorázový výzkum Scaffidiové a Bermanové (2011).

Za zvláštní pozornost stojí důkladný výzkum Åkerlinda z r. 2009. Autor oslovil 2500 postdoktorandů z 38 australských vysokých škol. Reálně se do výzkumu

1 V USA jsou to např. Graduate and Postdoctoral Education Committee of the Association of American Universities; National Postdoctoral Association. 
zapojilo 1011 postdoktorandů, kteří vyplnili dotazník. Z nich pak autor vybral ještě 22 postdoktorandů a vedl s nimi hloubkové rozhovory. Pohled posledně zmíněných postdoktorandů navíc obohatil o názory 10 mentorů, kteří tyto postdoktorandy po dokončení doktorského studia vedli. Nebudeme zabíhat do detailů, jen zkonstatujeme základní zjištění. Potvrdil se předpoklad, že postdoktorandi mají zájem převážně o akademickou kariéru. Pokud se dostanou na pracovní pozici výzkumníka, je to pro většinu z nich základ akademické kariéry. Z celkového počtu 1011 dotázaných postdoktorandů jich $41 \%$ hodlá pracovat na vysoké škole a provozovat jak výuku, tak výzkum. Dalších 32 \% se jich chce na vysoké škole věnovat pouze výzkumu.

Jen sporadicky se objevují longitudinální empirické výzkumy reálné situace postdoktorandů. Uved'me výzkum Američanů s českými předky (Nerad \& Cerny, 2002), který se zajímal o osud postdoktorandů př́rodovědných, technických a humanitních oborů 10 let po skončení studia.

Šlo o šetření, které zahrnulo 6000 absolventů z 61 amerických univerzit. Byli to absolventi Ph.D. studia biochemie, výpočetní techniky, elektroinženýrství, angličtiny, matematiky a politologie. Z těchto absolventů $53 \%$ pracovalo na vysokých školách (z toho 39 \% na místech výzkumných pracovníků, kde řešili granty). Dalších $33 \%$ zakotvilo v průmyslových podnicích a obchodních společnostech. Zbývajících $14 \%$ pracovalo ve státní správě, neziskových organizacích, v laboratořích, armádě a zdravotnictví.

Jaká je situace v Evropě? V německy mluvících zemích se pravidelně analyzuje kvalita doktorského studia a jeho absolventů. Výsledky bývají prezentovány ve výročních zprávách oborů, které se věnují výchově a vzdělávání (Tillmann et al., 2008; Thole et al., 2012). ${ }^{2}$

VČeské republice se uskutečnila dílčí jednorázová sonda, kterou organizovaly pracovnice Technické univerzity v Liberci. Byla provedena u 125 českých a polských doktorandů technických oborů (Neumannová \& Nejedlová, 2009). U doktorandů sonda zjištovala, s jakými představami budou vstupovat na trh práce; u potenciálních zaměstnavatelů se zase zajímala, jak jsou schopni motivovat absolventy doktorského studia k práci ve svých firmách a nakolik umožňují svým zaměstnancům další vzdělávání v oboru.

V České republice je to pouze Univerzita Karlova v Praze, která systematicky hodnotí kvalitu doktorského studia z pohledu absolventů a zjišt'uje jejich uplatnění v praxi.

2 Na tuto skutečnost mne upozornil anonymní recenzent. Děkuji mu za toto doplnění (včetně literárních odkazů). 
Byly provedeny tři výzkumné sondy, inspirované výzkumem Marshe et al. (2002), a to v letech 2005, 2007 a 2011. Zahrnuly celkem 2025 postdoktorandů. S odstupem 3-10 let od absolvování se postdoktorandi uplatnili takto: $45 \%$ působí na vysokých školách, $14 \% \mathrm{v}$ ústavech Akademie věd, $4 \%$ ve výzkumných institucích, $6 \%$ ve státní správě a $4 \%$ v průmyslových podnicích. Zbytek (4\%) je na rodičovské dovolené nebo je osobou samostatně výdělečně činnou. Jinak řečeno: akademické kariéře ve vystudovaném oboru se věnuje $81 \%$ postdoktorandů, $11 \%$ pracuje v př́buzném oboru a jen $7 \%$ nezůstalo v oboru a nevěnuje se akademické kariéře (Ježek \& Mareš, 2012). Zdálo by se, že 81 \% těch, kteří se věnují akademické kariéře ve svém oboru, je relativně vysoký podíl a mohli bychom být spokojeni. Je však třeba dodat, že postdoktorandi obvykle nenastupují na místa vědeckých pracovníků, ale na učitelská místa.

Nabízí se otázka, podle kterých kritérií vyhodnocovat kvalitu př́pravy postdoktorandů, jejich získávání dalších výzkumných zkušeností. Jeden z možných pohledů nabízí Davies (2009). Předložil dvě skupiny kritérií. První skupinu tvoří obecnější a spíše subjektivněji laděná kritéria: spokojenost s postdoktorandskou přípravou a subjektivně prožívaný přínos přípravy, kvalita vztahů s mentorem/konzultantem, absence konfliktů s mentorem/ konzultantem a absence špatného vedení postdoktoranda, odborná produktivita postdoktoranda. Druhou skupinu kritérií představují objektivnější ukazatele: individuální získávání grantů, roční příjem postdoktoranda, získávání benefitů k platu, kvalita plánu postdoktorandské přípravy, ukazatele profesionálního rozvoje postdoktoranda a zdravotní pojištění postdoktoranda.

Tolik stručný pohled na dosavadní výzkumy. Nyní je už čas podívat se důkladněji na situaci $\mathrm{v}$ doktorském studiu oboru Pedagogika na českých univerzitách.

\section{Výzkumná sonda}

\subsection{Zkoumaný soubor}

Doktorské studium ve studijním programu Pedagogika je zatím akreditováno na třech pedagogických fakultách a na dvou filozofických fakultách. Pokud jde o pedagogické fakulty, běží doktorské studium léta na Pedagogické fakultě UK Praha, Pedagogické fakultě MU v Brně a Pedagogické fakultě UP v Olomouci ${ }^{3}$.

3 Na Pedagogické fakultě UP v Olomouci je navíc akreditováno také doktorské studium $\mathrm{v}$ angličtině (Education). 
Pokud jde o filozofické fakulty, běží doktorské studium léta na Filozofické fakultě UK Praha a Filozofické fakultě MU v Brně. Zejména na Pedagogických fakultách (jak už bylo řečeno) se nepřipravují pouze doktorandi „čisté“ pedagogiky, ale také doktorandi některých oborových didaktik. Pro účely této studie - s vědomím určitého zjednodušení - budeme mluvit o absolventech doktorského studijního programu Pedagogika jako o celku.

\subsection{Použité metody}

Zjistit počty úspěšných absolventů doktorského studia Pedagogika za uplynulé období nebylo snadné. Volili jsme dvě cesty. Protože absolventů doktorského studia na pedagogických fakultách je mnoho, požádali jsme tajemníka Akreditační komise J. Smrčku, aby nám poskytl data z matriky studentů a absolventů, která je vedena na MŠMT. Jednalo se o období od jejího založení do současnosti, tj. za léta 1999-2011. Ochotně vyhověl a dodal oficiální data. Absolventů doktorského studia na filozofických fakultách je relativně méně, a proto jsme požádali vedení Katedry pedagogiky FF UK a vedení Ústavu pedagogických věd FF MU o potřebná data za stejné období (1999-2011). Také ochotně vyhověli.

\section{$4 \quad$ Výsledky}

Počty absolventů doktorského studia Pedagogika na českých pedagogických fakultách se proměňovaly v čase. Celkem jich v uvedených 13 letech absolvovalo 509.

Počty absolventů doktorského studia Pedagogika na českých filozofických fakultách se rovněž proměňovaly v čase, i když byly výrazně nižší, celkem jich v uvedených letech absolvovalo 40.

Souhrnný pohled na počty všech absolventů oboru Pedagogika přináší obr. 1. 


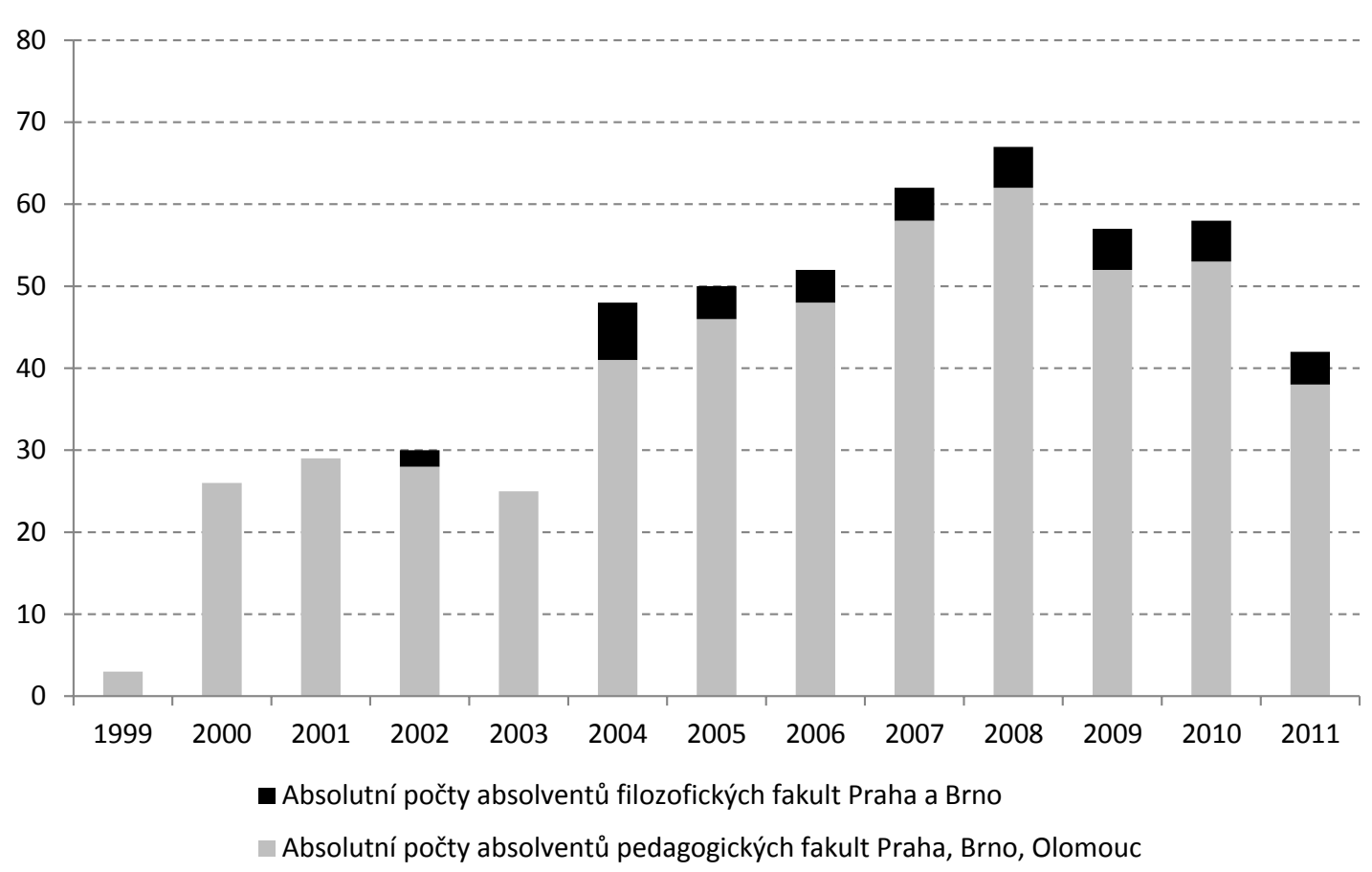

Obrázek 1. Počty absolventů doktorského studia Pedagogika na českých pedagogických a filozofických fakultách v letech 1999-2011.

Souhrnně řečeno: v letech 1999-2011 úspěšně dokončilo doktorské studium v oboru Pedagogika v České republice 549 osob. Pokud bychom tento údaj mechanicky zprůměrovali, vyjde nám, že každý rok opouštělo české fakulty 42 nových badatelů - postdoktorandů v pedagogice.

Měli by to být postdoktorandi, kteř́i jsou připraveni kvalifikovaně provádět pedagogický výzkum, vnášet do něj nové myšlenky, přinášet nová výzkumná data. Jsou to lidé, $\mathrm{z}$ nichž se konstituuje střední generace výzkumníků. Právě z nich by se postupně měli rekrutovat budoucí docenti a profesoři. Kde jsou a proč - jak se nám zdá - při tolika stech postdoktorandů nedošlo k výraznému omlazení badatelských kolektivů ani k zásadnímu posunu v českém pedagogickém výzkumu?

\section{Zamyšlení nad domácím kontextem}

Dřive, než budeme diskutovat údaje o absolventech doktorského studia Pedagogiky, je vhodné se zamyslet nad tím, proč se mladí lidé i lidé středního věku vydávají na tuto dráhu, proč usilují o absolvování doktorského studia. 
Největší skupinu zájemců tvoří učitelé, kteří již jsou v praxi a působí na vysokých školách. Jsou svojí institucí tlačeni k tomu, aby si zvýšili kvalifikaci a pracoviště mělo odpovídající kvalifikační strukturu. Jen část z nich se vydává na studium ze zájmu o zkoumání pedagogických problémů, zbývající studium berou spíše jako formální krok, který však má existenční dopady. Jsou i tací, pro něž je získání titulu Ph.D. nutnou, nikoli postačující podmínkou ke kariérnímu vzestupu. Pro vedení kateder je doktorské studium nástrojem, jak přimět učitele $\mathrm{k}$ vědecko-výzkumné činnosti a k získávání publikačních bodů pro pracoviště.

Druhou skupinou jsou čerství absolventi magisterského studia, kteří by se chtěli v budoucnu pedagogice hlouběji věnovat, i když ještě přesně nevědí, co skutečná vědecko-výzkumná činnost obnáší a jaké oběti budou muset přinést. ${ }^{4}$

Třetí skupinou mohou být pracovníci výzkumných institucí a čtvrtou skupinou jsou nejvíce motivovaní učitelé nižších stupňu škol (středních i základních). U posledně jmenovaných zůstává otázkou, nakolik se mohou skutečně věnovat vědeckému výzkumu $\mathrm{v}$ plném slova smyslu. $\mathrm{U}$ těch nejlepších obvykle jde o spoluúčast $v$ týmu, který řeší témata aplikovaného výzkumu, nikoli o samostatnou vědeckou práci. Někteří učitelé základních a středních škol nepředpokládají, že by se soustavně věnovali badatelské práci, spíše je zajímají inovace. Dalším učitelům doktorské studium slouží ke zlepšení pozice $\mathrm{v}$ učitelském sboru. Někteří navíc nepocitují výrazný rozdíl mezi rigorózním řízením, které končí titulem PhDr. a doktorským studiem, které končí titulem Ph.D.

První a třetí skupina studuje v kombinované formě studia; absolvují tedy vědeckou př́ípravu při zaměstnání. Jejich věkové složení je široké, nejde pouze o mladé začínající badatele.

Obr. 1 znázorňuje určité vývojové trendy v doktorském studiu oboru Pedagogika: po počátečních skromných začátcích (na pedagogických fakultách roku

\footnotetext{
Pro zajímavost uvádíme důvody, které zjistili badatelé u absolventů magisterského studia psychologie, když se jich ptali, proč chtějí pokračovat v doktorském studiu: (1) vysoký zájem o obor, (2) lepší pozice na trhu práce, (3) titul je prestižní záležitostí, (4) doktorské studium umožňuje cestovat do zahraničí, (5) chci si prodloužit studentský život, (6) chci učit na vysoké škole, (7) baví mě výzkum (Neusar \& Charvát, 2012, s. 57). Přitom ponecháváme stranou ostudnou výši stipendií pro doktorandy prezenční formy studia, zejména v prvních ročnících studia.
} 
1999, na filozofických fakultách později, až roku 2002, nastupuje období určité stabilizace, kdy se počet absolventů pohybuje ročně mezi 25-30 osobami (léta 2000-2003). Od roku 2004 se zvyšuje počet absolventů až do r. 2008. Poté nastupuje mírný pokles. Čím tyto změny vysvětlit? Důvody, proč stoupaly počty absolventů, zřejmě jsou: zvyšování počtu školitelů, důraz na hodnocení kvality práce fakult podle počtu doktorandů (a zejména úspěšně dokončivších doktorandů), nutnost saturovat potřebu oborových didaktiků. Jistý pokles od r. 2009 je dán mj. zvyšováním nároků Akreditační komise na kvalitu doktorského studia, osamostatňováním se řady oborových didaktik, povinností vysokých škol zpřístupňovat na webu obhájené disertační práce (tím stoupá veřejná kontrola kvality disertací).

To byl převážně kvantitativní pohled. Jaký je další osud těch, kteří úspěšně dokončí doktorské studium? Většina $\mathrm{z}$ nich se vrací do svých institucí. Tito postdoktorandi mají v ruce doklad, že absolvovali vědeckou př́ípravu, ale málokdo $\mathrm{z}$ nich se obvykle začne vědecko-výzkumné činnosti věnovat převážnou částí svého úvazku. Důvody jsou podle našeho názoru tyto:

- Malý počet míst v rezortních výzkumných ústavech, nebot' bývalý ministr školství J. Dobeš administrativním rozhodnutím snížil počet rezortních ústavů a hlavně počet jejich odborných zaměstnanců. Tři instituce - Národní ústav odborného vzdělávání, Výzkumný ústav pedagogický, Institut pedagogicko-psychologického poradenství - sloučil do jednoho menšího pracoviště nazvaného Národní ústav pro vzdělávání. Převedl tam zbylé pracovníky, takže mladí zájemci o výzkum nemají možnost se zde uplatnit. Naopak řada zkušených výzkumníků si musela hledat nového zaměstnavatele.

- Poté, co na vysokých školách nedávno skončily velké výzkumné projekty typu výzkumných center a výzkumných záměrů, je obtížné udržet pohromadě dosavadní výzkumné týmy. Určitou možností je operační program Vzdělávání pro konkurenceschopnost (zkráceně OPVK), který je zaměřen na zkvalitnění a modernizaci systémů počátečního, terciárního a dalšího vzdělávání, k jehož řešení se některé fakulty přihlásily. Program je financován z Evropského sociálního fondu. Skutečností však je, že v současné době, kdy je financování vysokých škol problematické, fakulty nechtějí rozšiřovat počty svých stávajících pracovníkủ. Proto je obtížné do dosavadních týmů včlenit nové, mnohdy perspektivní mladé badatele. Pro individuální výzkumné projekty nabízí určitý prostor Grantová agentura ČR, kde se jedná o specificky postdoktorandské granty. 
- Pokud se čerství absolventi doktorského studia oboru Pedagogika vracejí na katedry pedagogiky svých fakult nebo do učitelských sborů středních a základních škol, slýchají zpravidla tato slova: Je dobře pro vás osobně i pro naše pracoviště, že jste si zvýšili kvalifikaci, ale my jsme především servisní katedra (my jsme především škola) a náplní naší práce je hlavně vyučovat žáky a studenty. Je interní věcí katedry a fakulty, jak se s podvojnou rolí vysokoškolského učitele vyrovná. Jinak řečeno: záleží na tom, jaká organizační kultura na pracovišti převládne.

- Navíc jsou zde vnější tlaky. České vysoké školy už přestávají být financovány pouze „kapitační platbou“ (tj. podle počtu studentů) a přibývá další kritérium - vědecko-výzkumná činnost. To způsobuje, že grantové agentury jsou zahlceny žádostmi o financování výzkumných projektů. Přitom se částky přidělované na vědu nijak výrazně nezvyšují. Z toho plyne, že pro pracovníky pedagogických a filozofických fakult je stále obtížnější uspět ve velké konkurenci a získat výzkumný grant s pedagogickým zaměřením. Zdálo by se, že kritérium výzkumné činnosti přeje postdoktorandům. Není to tak docela pravda, nebot' při žádostech o výzkumné granty se uchazeč musí prokázat předchozí bohatou výzkumnou a publikační činností. Toto hledisko postdoktorandi zpravidla nesplňují a agentury se zdráhají udělit grant někomu, kdo není (zatím) v odborné komunitě známý.

- Do výstupů z výzkumné činnosti se už pro potřeby financování vysokých škol nezapočítávají jakékoli publikační výstupy (např. články v běžných sbornících z různých domácích konferencí, články v lokálních sbornících a lokálních časopisech). V úvahu se berou jen články, které byly publikovány: (a) v impaktovaných časopisech uváděných v databázi Web of Science; (b) v časopisech, které jsou vedeny ve světově uznávaných databázích ERIH, SCOPUS; (c) v časopisech, jež figurují na pozitivním seznamu Rady vlády pro výzkum, vývoj a inovace (Seznam..., 2010) ${ }^{5}$. Dále se fakultám do vědecké činnosti počítají odborné knihy, kapitoly v odborných knihách a článek ve sborníku, který je evidován ve světové databázi

\footnotetext{
Na seznamu Rady vlády figurovaly v r. 2010 tyto pedagogické časopisy (s primárním identifikačním kódem AM): AULA, Biologie-Chemie-Zeměpis, Didaktické studie, Envigogika, e-Pedagogium, Geografické rozhledy, Hudební výchova, Journal of Technology and Information Education, Journal of Efficiency and Responsibility in Education and Science, Media4u Magazine, Orbis scholae, Paidagogos, Pedagogická orientace, Pedagogika, Studia Paedagogica, Výtvarná výchova, Zpravodaj pedagogicko-psychologického poradenství.
} 
Conference Proceedings společnosti Thomson Reuters. Tímto zpřísněním kritérií se opět snížily šance mnohých fakult připravujících učitele, aby získaly body za své vědecko-výzkumné aktivity a tím i finance na jejich provozování. ${ }^{6} \mathrm{~V}$ oboru Pedagogika se tak kvalitní výzkumná činnost v ČR soustředila do tří pracovišt': Ústavu výzkumu a rozvoje vzdělávání Pedagogické fakulty UK Praha, Institutu výzkumu školního vzdělávání Pedagogické fakulty MU Brno a Ústavu pedagogických věd Filozofické fakulty MU Brno.

Z toho, co bylo uvedeno, je zřejmé, že těch postdoktorandů, kteří se po úspěšném dokončení vědecké přípravy mohou věnovat vědě profesionálně, jsou řádově desítky, zatímco studium jich úspěšně dokončily stovky.

Další důvod, proč se postdoktorandi jen obtížně začleňují do vědecké komunity, je skrytý. Spočívá v koncepci doktorského studia humanitních oborů a pedagogiky zvláště. Zmínili jsme již různé typy uchazečů o doktorské studium, kteří přicházejí z různých prostředí a mají rozdílné představy o svém budoucím uplatnění. Tyto rozdílné skupiny doktorandů procházejí u nás $\mathrm{v}$ zásadě stejným typem vědecké přípravy. Rozdíly jsou jen v možnosti přibrat si specificky zaměřené volitelné předměty či kursy a v tématech disertačních prací.

\section{Zamyšlení nad zahraničním kontextem}

Ve vyspělých zemích mívá doktorské studium rozdílné podoby. Zájemce se může vydat různými cestami $\mathrm{k}$ různým titulům. Např. australská autorka Maxwellová (2009) provedla kvalitativní výzkum na Pedagogické fakultě Royal Melbourne Institute of Technology (RMIT), veřejné výzkumné univerzitě, a vedla rozhovory s 17 doktorandy oboru Pedagogika a 6 školiteli. Na dané univerzitě fungovaly tři podoby doktorského studia (tab. 1).

\footnotetext{
Na některých katedrách pracovníci rezignují na kvalitní publikace (viz slogan „Na nás a naše podmínky je to dost dobrá publikace.") a hledají cestičky, jak své publikace alespoň někde uplatnit a snadněji získat akademické tituly. Na jiných katedrách naopak vysílají mladší pracovníky na konference a stáže do zahraničí, hledají spolupracovníky na špičkových pracovištích a snaží se zkvalitnit svoji vědeckou produkci (viz slogan „Měli bychom dosáhnout úrovně běžné venku.").
} 
Tabulka 1

Tři typy doktorského studia v oboru Pedagogika na RMIT University

\begin{tabular}{|c|c|c|c|}
\hline $\begin{array}{l}\text { Vybraná } \\
\text { hlediska }\end{array}$ & $\begin{array}{l}\text { Doktorské studium } \\
\text { založené na disertaci } \\
\text { s vyváženým podílem } \\
\text { teorie a empirického } \\
\text { výzkumu } \\
\text { (PhD by thesis) }\end{array}$ & $\begin{array}{l}\text { Doktorské studium } \\
\text { založené na prakticky } \\
\text { zaměřeném } \\
\text { výzkumném projektu } \\
\text { (PhD by project) }\end{array}$ & $\begin{array}{l}\text { Doktorské studium } \\
\text { založené na profesním } \\
\text { rozvoji praktika }\end{array}$ \\
\hline Cíl přípravy & $\begin{array}{l}\text { vysoce kvalifikovaný } \\
\text { badatel především pro } \\
\text { základní výzkum }\end{array}$ & $\begin{array}{l}\text { kvalifikovaný výzkumník } \\
\text { pro aplikovaný výzkum }\end{array}$ & $\begin{array}{l}\text { učitel na škole, který } \\
\text { je schopen prosazovat } \\
\text { inovace }\end{array}$ \\
\hline $\begin{array}{l}\text { Výzkum se } \\
\text { provádí }\end{array}$ & $\begin{array}{l}\text { na univerzitě nebo } \\
\text { v terénu; nemívá } \\
\text { vztah k doktorandovu } \\
\text { pracovišti }\end{array}$ & $\begin{array}{l}\text { na různých typech škol, } \\
\text { v podnicích, kde se } \\
\text { vzdělávají zaměstnanci }\end{array}$ & $\begin{array}{l}\text { na vlastním pracovišti } \\
\text { doktoranda, obvykle } \\
\text { na dané škole a blízkých } \\
\text { školách }\end{array}$ \\
\hline $\begin{array}{l}\text { Předpokládané } \\
\text { výstupy }\end{array}$ & $\begin{array}{l}\text { teoretické modely, } \\
\text { zjišt’ování vztahů mezi } \\
\text { proměnnými, nové } \\
\text { diagnostické nástroje } \\
\text { a intervence }\end{array}$ & $\begin{array}{l}\text { prokazatelný materiální } \\
\text { produkt, změna } \\
\text { ve fungování instituce }\end{array}$ & $\begin{array}{l}\text { dílčí inovace, zvýšení } \\
\text { odborné kvalifikace } \\
\text { učitele, akční výzkum }\end{array}$ \\
\hline $\begin{array}{l}\text { Počet partnerů } \\
\text { při výzkumu }\end{array}$ & doktorand - univerzita & $\begin{array}{l}\text { doktorand - univerzita - } \\
\text { vybrané spolupracující } \\
\text { instituce }\end{array}$ & $\begin{array}{l}\text { doktorand - univerzita - } \\
\text { pracoviště doktoranda }\end{array}$ \\
\hline $\begin{array}{l}\text { Doktorandova } \\
\text { motivace ke } \\
\text { studiu }\end{array}$ & $\begin{array}{l}\text { osobní uspokojení, } \\
\text { zájem o dané téma, } \\
\text { uplatnění se v oboru }\end{array}$ & $\begin{array}{l}\text { odborná kariéra, zájem } \\
\text { o dané téma, dovednost } \\
\text { navrhovat a řešit } \\
\text { projekty }\end{array}$ & $\begin{array}{l}\text { profesní rozvoj, zvýšení } \\
\text { sociální statusu } \\
\text { na pracovišti, osobní } \\
\text { uspokojení }\end{array}$ \\
\hline
\end{tabular}

Pozn.: modifikovaně podle Maxwellové (2009).

Je důležité dodat, že třetí typ doktorského studia (EdD), byl na zmíněné univerzitě otevřen v r. 1997. Po deseti letech bylo zastaveno přijímání dalších studentů, nebot' jak kvalita uchazečů, tak i přijatých studentů nesplňovala univerzitní standardy doktorského studia.

Práci Maxwellové zmiňujeme proto, že s obdobnými problémy zápasí také fakulty našich univerzit. Pro řadu českých učitelů ze základních a středních škol, kteří se zajímají o inovace, by možná bylo vhodnější absolvovat rigorózní řízení zakončené akademickým titulem než úplnou vědeckou přípravu. Obecně řečeno: měli bychom si v České republice definovat, co je ještě akceptovatelné jako solidní vědecká příprava a co už nikoli. Vždyt' 
nekvalitními doktorskými disertacemi se snižuje vážnost oboru Pedagogika v očích představitelů jiných oborů.

Doktorandi jsou zvyklí, že během své odborné přípravy zastávají několik sociálních rolí současně:

- $\quad$ studentskou roli při plnění studijních povinností;

- výzkumnickou roli při realizaci výzkumu;

- učitelskou roli při vedení výuky;

- $\quad$ kolegiální roli při kooperaci s kolegy na pracovišti;

- expertní roli při prezentování odborných poznatků odborné nebo laické veřejnosti. (Neusar \& Charvát, 2012, s. 223)

Tato situace se ještě zkomplikuje, když studium úspěšně dokončí. Okolí na ně začne pohlížet jako na kvalifikované badatele. Přitom by mnozí z nich potřebovali určité „přechodné období", kolegiální pomoc a vedení zkušeným badatelem, aby si na tuto novou roli zvykli a naplnili ji po svém.

Podívejme se na hypotetický příklad. Týká se postdoktoranda, který absolvoval kombinovanou formu studia (studoval tedy při zaměstnání) a působí po celou dobu na svém původním pracovišti. Z doktorského studia, které čerstvě absolvoval, bývá odborně lépe připraven než jeho spolupracovníci. Ze sociálního srovnávání na svém pracovišti vychází lépe, nebot' - jak dokládají výzkumy - výsledek sociálního srovnávání lidí záleží na sociálním kontextu srovnávání. Tím se může stát nebezpečným pro kolegy: vyrostl jim v konkurenci, kterou oni musí brát vážně. Je vystaven sociálnímu tlaku, na nějž může zareagovat třemi možnostmi: konformitou, konfrontací, anebo odchodem na jiné pracoviště. Příklad se týkal sociálních vztahů na pracovišti.

Druhý př́klad se týká sebepojetí postdoktoranda. Psychologové Marsh a Parker (1984) se zamýšleli nad tím, co udělá sociální kontext se sebepojetím člověka, a odhalili efekt, který metaforicky nazvali „velká ryba v malém rybníce" (big-fish-little-pond). Marsh et al. (2008) uvádí příklad tří žáků, ale jeho př́íklad můžeme pro naše téma modifikovat pro tři učitele. Představme si tři stejně schopné a stejně výkonné učitele $\mathrm{X}, \mathrm{Y}$ a $\mathrm{Z}$, kteří absolvovali doktorské studium. První učitel $X$ působí na pracovišti, $v$ němž je většina kolegů výkonnostně slabších než on. Druhý učitel Y působí na pracovišti, kde jsou kolegové výkonnostně zhruba na stejné úrovni, jako je on. Třetí učitel Z se dostane na výzkumné pracoviště, kde je většina kolegů výkonnostně lepší než on. Otázka zní, co to v delším časovém období udělá s jejich sebepojetím, 
s jejich motivací se zlepšovat a s jejich vědeckým výkonem. Efekt „velké ryby v malém rybníce“ předpovídá: učitel X bude mít vysoké sebepojetí a nebude mít potřebu se sebou něco dál dělat. Čeština má pro tento př́ípad výstižné úsloví: mezi slepými jednooký králem. Učitel Y bude mít sebepojetí průměrné, zatímco učitel $\mathrm{Z}$ ho bude mít nízké; nebude si věřit, po několika marných pokusech rezignuje na to, aby se lepším kolegům vyrovnal. Covington (2000) k posledně uvedenému případu dodává: ve vysoce soutěživém prostředí bývá málo vítězů a mnoho poražených, a proto se sebepojetí osob na takových pracovištích snižuje.

\section{7 Úrovně uvažování o problému}

$\mathrm{V}$ předchozím textu jsme předložili zjištěná data a uvažovali jsme nad možnými příčinami stavu, který nelze v České republice označit za dobrý. Nabízí se tedy otázka, na kterých úrovních hledat řešení.

\section{1 Životní dráha}

První - velmi obecné řešení - se nabízí samo: mnohem detailněji prozkoumat reálnou situaci, tj. longitudinálně sledovat životní dráhu postdoktorandů. Popsat a analyzovat faktory, které ji ovlivňují: osobnostní, odborné, ekonomické, pracovní, legislativní, rodinné a nezapomínat na širší sociální kontext, v němž se vše odehrává.

\section{2 ̌ě̌ení na různých úrovních}

Druhý způsob uvažování je složitější a rozdělíme ho do šesti úrovní. Z těchto šesti úrovní může doktorand sám ovlivnit (do jisté míry) pouze úroveň první, individuální.

\section{Individuální úroveň}

Postdoktorandi jsou velmi zranitelnou skupinou těch pracovníků, kteří se zabývají vědecko-výzkumnou činností (Cozzens et al., 1990; Laudel \& Glässer, 2008). Pokud se postdoktorand dostane do vědecko-výzkumné instituce, může projít čtyřmi etapami své profesní dráhy: zpočátku je pouhý učeň, pak kolega a později zkušený badatel, který může být mentorem pro další generaci. Čtvrté etapy, tj. úrovně elitního badatele, dosahuje jen malá část vědecko-výzkumných pracovníků (Dalton, Thompson, \& Price, 1977). 
Lauder a Glässer (2008) navrhli poněkud jiná hlediska při posuzování doktorandů jako jednotlivců a ověřili je na 16 postdoktorandech. Na základě strukturovaného rozhovoru se vyplňuje formulář, který zachycuje životní dráhu začínajícího vědecko-výzkumného pracovníka (Lauder \& Glässer, 2008, s. 394). Sledují se tři kritéria: (a) vývoj postdoktorandovy kariéry v rámci dané instituce, především přechod od začátečníka k plnohodnotnému kolegovi; (b) vědecko-výzkumná kariéra od doktorské disertace přes spoluřešitelství na projektech jiných lidí až po samostatný výzkumný projekt, v němž je postdoktorand hlavním řešitelem; (c) kariéra $\mathrm{v}$ rámci vědecké komunity (publikace vzniklé pod supervizí mentora; publikace, kde je spoluautorem; publikace, kde je hlavním autorem; vývoj citačních ohlasů; vývoj tematického zaměření jeho výzkumů).

\section{Úroveň pracoviště, např. katedry, ústavu, institutu}

Rozlišíme dvě situace. Postdoktorand, který už v dané instituci pracuje, zná její chod a je zvyklý vyučovat, může hledat prostor pro to, aby mohl bádat. Může se začlenit do projektu, který už na pracovišti běží a dostane od hlavního řešitele vymezeno výzkumné pole. Nebo je mu doporučeno, aby si sám koncipoval výzkumný projekt, získal spolupracovníky a pokusil se $\mathrm{s}$ projektem uspět $\mathrm{v}$ grantové soutěži. Vedení pracoviště předpokládá (ne vždy oprávněně), že po dokončení doktorského studia už je naprosto samostatným a zkušeným výzkumníkem.

Druhá situace se týká mladého postdoktoranda, který právě skončil svou vědeckou př́pravu a čerstvě nastoupil na nové pracoviště. Obvykle není přijímán na vědecké, nýbrž učitelské místo a musí se adaptovat na podmínky, které jsou pro něho nové.

$\mathrm{V}$ obou případech je výhodné, aby na daném pracovišti fungoval institut „uvádějícího výzkumníka“ (mentora), tj. zkušeného badatele, který dokáže těm, kteří začínají se samostatnou vědeckou prací, poradit a pomoci. Dál se vzdělávají a cvičí si vědecké dovednosti pod jeho supervizí (Muniyappa, 2007). Ne vždy taková ideální situace nastane, nebot' řada starších badatelů si nechce vychovat konkurenty a případné nástupce. Pak nastupuje druhé řešení, kdy se mladší učitelé sdružují, v mezích možností si radí navzájem, jezdí po konferencích a hledají „spřízněné duše“ mimo své pracoviště. Nacházejí mentora v jiné instituci, ba i v jiné zemi.

Postgraduální vzdělávání a výcvik, které vede na daném pracovišti mentor, bývá někdy záležitostí ad hoc, kdy se řeší především aktuální problémy, 
s nimiž se začínající pracovník potýká. Může mít však podobu promyšleného kurikula, zejména v oborech, kde velmi záleží na kvalitní práci s lidmi. Určitou inspirací by pro pedagogiku mohla být koncepce postdoktorandského vzdělávání a výcviku, která je realizována v americké poradenské psychologii (viz obr. 2).

\section{Zastřešující principy}

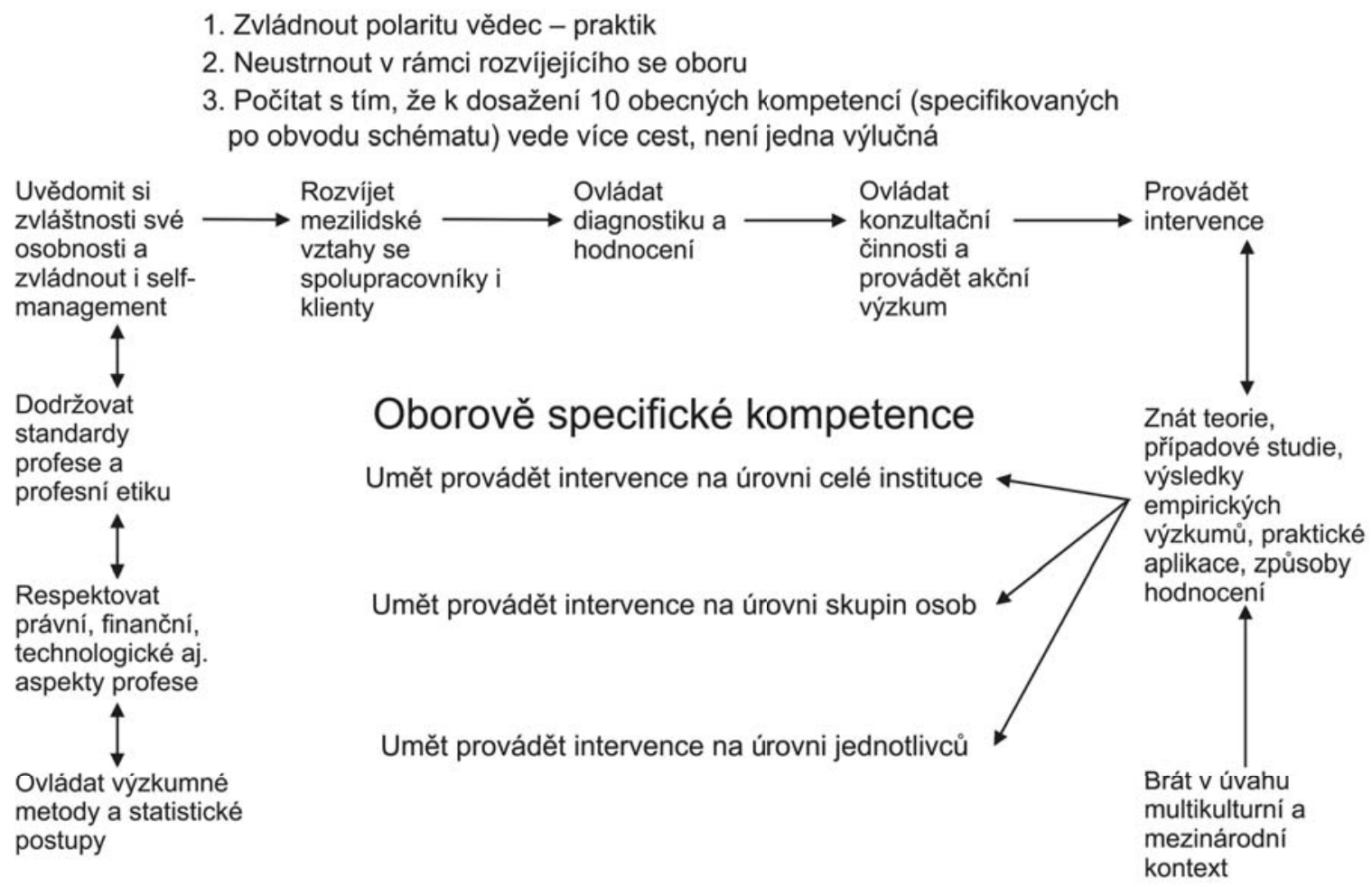

Obrázek 1. Koncepce postdoktorandského vzdělávání a výcviku v poradenské psychologii (modifikovaně podle APA, 2007, s. 981)

Úroveň instituce jako celku, např. univerzity, výzkumného ústavu

České instituce teprve začínají se systematickou prací s postdoktorandy. Lze to doložit analýzou Výročních zpráv o činnosti za rok 2011 u tří největších univerzit. Univerzita Karlova v Praze (Výroční zpráva UK, 2012) nemá v textu žádnou zmínku o postdoktorandech. Masarykova univerzita v Brně (Výroční zpráva $M U, 2012$, s. 50) zmiňuje, že byl schválen projekt, v jehož rámci během tří dalších let bude vytvořeno 57 míst pro postdoktorandy - začínající výzkumníky. Není však uvedeno, kterých fakult či vědních oborů se to bude týkat. Univerzita Palackého v Olomouci (Výroční zpráva UP, 2012, s. 50) je 
patrně nejdál. V rámci rozvojového podprojektu MŠMT Internacionalizace získala nejprve finance na vypsání postdoktorandských míst pro zahraniční odborníky. Ze 22 uchazečů bylo vybráno 7 zahraničních postdoktorandů, kteří pobyli na UP Olomouc půl roku. Z dalšího projektu Podpora vytváření excelentních výzkumných týmů byly získány zdroje, které umožní vytvořit 55 postdoktorandských míst na šesti fakultách. Zatím se zdá, že se tento projekt netýká Pedagogické fakulty; přednost mají fakulty lékařská, př́rodovědecká, filozofická, tělesné kultury apod.

Jednou z možných inspirací, jak pracovat s postdoktorandy, může být doporučení, která zavádějí výzkumné instituce v zahraničí, zejména ty, jejichž náplní je převážně výzkum. Jeden z možných příkladů přináší tab. 2.

Tabulka 2

Systém práce s postdoktorandy ve firmě Sandia National Laboratories v USA

\begin{tabular}{|c|c|c|c|}
\hline & Postdoktorand & Jeho mentor & Manažer dané instituce \\
\hline $\begin{array}{l}\text { Nezávislost/ } \\
\text { samostatnost } \\
\text { a role pracovníků } \\
\text { daného } \\
\text { pracoviště }\end{array}$ & $\begin{array}{l}\text { Je pod supervizí } \\
\text { staršího zkušeného } \\
\text { výzkumného } \\
\text { pracovníka. }\end{array}$ & $\begin{array}{l}\text { Pravidelně } \\
\text { kontroluje a vede } \\
\text { postdoktoranda při } \\
\text { řešení výzkumného } \\
\text { projektu. } \\
\end{array}$ & $\begin{array}{l}\text { Kontroluje a usměrňuje } \\
\text { výzkumnou činnost na } \\
\text { pracovišti (časově podle } \\
\text { potřeby, ale nejméně } \\
\text { jednou za půl roku). }\end{array}$ \\
\hline Očekávání aktérů & $\begin{array}{l}\text { Chce prokázat } \\
\text { svoji výzkumnou } \\
\text { produktivitu a podávat } \\
\text { takové výkony, které } \\
\text { umožnují dosahovat } \\
\text { stanovených } \\
\text { výzkumných cílů. } \\
\text { Chce potvrdit pozici } \\
\text { mladého vědeckého } \\
\text { pracovníka a udržet } \\
\text { se v ní. }\end{array}$ & $\begin{array}{l}\text { Chce usměrňovat } \\
\text { kariérní růst } \\
\text { svěřeného } \\
\text { postdoktoranda, } \\
\text { poskytovat mu } \\
\text { zpětnou vazbu. } \\
\text { Postupně ho } \\
\text { připravovat pro } \\
\text { další pracovní } \\
\text { pozici. }\end{array}$ & $\begin{array}{l}\text { Hodlá sledovat práci } \\
\text { postdoktoranda s ohledem } \\
\text { na předpokládaný } \\
\text { další kariérní postup } \\
\text { a včas reagovat na práci } \\
\text { postdoktoranda. } \\
\text { Usměrňuje } \\
\text { postdoktoranda, aby } \\
\text { navázal kontakty s dalšími } \\
\text { postdoktorandy a zapojil } \\
\text { se tak do sítě odborných } \\
\text { vztahů. }\end{array}$ \\
\hline $\begin{array}{l}\text { Získávání dalších } \\
\text { finančních } \\
\text { prostředků }\end{array}$ & $\begin{array}{l}\text { Souhlasí s tím, že přejde } \\
\text { na vyšší úroveň své } \\
\text { odbornosti. } \\
\text { Nastupuje na } \\
\text { pracoviště, které } \\
\text { prověŕí, zda } \\
\text { postdoktorand umí } \\
\text { aplikovat osvojené } \\
\text { praktické dovednosti } \\
\text { a realizovat výzkum. }\end{array}$ & $\begin{array}{l}\text { Mentor } \\
\text { může přibrat } \\
\text { postdoktoranda } \\
\text { jako spoluřešitele } \\
\text { nově podávaných } \\
\text { výzkumných } \\
\text { projektů. }\end{array}$ & $\begin{array}{l}\text { Navrhuje směry, jimiž } \\
\text { lze zlepšit financování } \\
\text { výzkumné činnosti } \\
\text { pracoviště v budoucnu. }\end{array}$ \\
\hline
\end{tabular}

Pozn.: modifikovaně podle Biedermannová et al. (2012, s. 8). 


\section{Úroveň odborných společností}

Odborné společnosti (např. Česká pedagogická společnost, Česká asociace pedagogického výzkumu) by mohly podpořit další odborný růst postdoktorandů např. vyhlašováním cen, které jsou určeny mladým vědeckým pracovníkům a jsou spojeny s finanční odměnou a publicitou. Může jít třeba o cenu za nejlepší publikovanou monografii, za původní výzkumný článek, za nejlepší referát na konferenci, za nejlepší poster na konferenci atp. V české pedagogice tato úroveň ocenění mladých vědeckých pracovníků není zatím dost propracovaná (na rozdíl např. od lékařských oborů).

\section{Celostátní úroveň vysokého školství a výzkumných institucí}

Ve vyspělých zemích už delší dobu funguje edukace postdoktorandů (postdoctoral education), chápaná jako zprostředkující článek, který usnadňuje čerstvým absolventům přechod od postgraduálního studia do reálné praxe. Nejčastěji mívá podobu stáží a zácviků (postdoctoral fellowship). Jsou určeny především pro absolventy prezenční formy doktorského studia, již mají relativně málo zkušeností s rutinní vědecko-výzkumnou činností.

Pokud jde o Českou republiku, MŠMT v r. 2011 otevřelo program tzv. postdoktorandských pozic, který je financován z evropských zdrojů prostřednictvím Operačního programu Vzdělávání pro konkurenceschopnost. Cílem programu je, aby nejlepší mladí výzkumníci po skončení doktorského studia nastoupili do českých univerzit a českých vědecko-výzkumných institucí. MŠMT chce tímto opatřením posílit mobilitu mezi jednotlivými institucemi a soukromým či veřejným sektorem, ale také zapojit začínající vědecké pracovníky do mezinárodních projektů. Dát jim prostor doma ${ }^{7}$, aby neodcházeli do zahraničí. Postdoktorandská místa jsou obsazována na základě výběrových řízení. Navrhovatelé tohoto projektu doufají, že česká výzkumná pracoviště se stanou otevřenějšími, posílí se v nich konkurence a tím i motivace stálých zaměstnanců. To by mohlo vést ke zvýšení kvality a efektivity výzkumu u nás (MŠMT, 2011).

Jak v zahraničí, tak i u nás však získat plný úvazek v nějaké instituci na 1-3 roky není pro řadu postdoktorandů dosažitelné. Proto se v zahraničí

Zatím je do projektu zapojeno sedm institucí: Mikrobiologický ústav AV ČR, Ústav makromolekulární chemie AV ČR; Masarykova univerzita, Mendelova univerzita v Brně, Jihočeská univerzita v Českých Budějovicích, Univerzita Hradec Králové a Fakultní nemocnice u sv. Anny v Brně. 
objevují alternativní řešení. Např. postdoktorandi ve vědním oboru ošetřovatelství (nursing) mají možnost se přihlásit do letní školy pro postdoktoran$d y$ (Gennaro, Deatrick, \& Dobal, 2007). Letní škola trvá dva roky a má tuto podobu: první rok v letních měsících postdoktorandi absolvují dva týdny př́imé výuky (celkem 60 vyučovacích hodin) a dále 30 hodin samostudia (část před kursem, aby přrišli připraveni, a část po skončení kursu, aby si naučené učivo procvičili). Druhý rok absolvují v letních měsících opět dva týdny př́mé výuky (celkem 60 vyučovacích hodin) a dále 20 hodin samostudia (část před kursem, aby přišli připraveni, a část po skončení kursu, aby si naučené učivo procvičili). Výstupem druhého roku je kvalitně vypracovaný výzkumný projekt, který lze ihned podat do některé z grantových agentur.

Kromě toho do hry vstupují také Asociace postdoktorandů, tj. občanská sdružení těch, kterých se problémy po dokončení doktorského studia nejvíce týkají. Vznikaly nejprve v USA a zpočátku řešily praktické problémy typu tabulkových platů, zdravotního pojištění, zdravotní péče, jako např jedna z prvních asociací - John Hopkins University Postdoctoral Association. Později se sdružily v celostátní asociaci, která v USA prosadila minimální nástupní plat, standardizovaný uvádějící program pro postdoktorandy a strukturované mentorování (Aschwanden, 2006). V Evropě tyto snahy teprve začínají a iniciativy se ujala Asociace evropských výzkumných univerzit.

\section{Nadnárodní úroveň}

V roce 2007 pořádala Humboldtova nadace v Berlíně konferenci o postdoktorandském studiu. Účastníci konference konstatovali, že celosvětově narůstá potřeba kvalitních vědeckých pracovníků a právě postdoktorandi jsou na mezinárodním trhu pracovních př́ležitostí velmi žádaným artiklem. Výzkumné instituce si uvědomují, že je třeba vytvořit fungující systém postdoktorandského vzdělávání a výcviku, aby mladí badatelé mohli získat výzkumné zkušenosti dříve, než nastoupí do trvalého pracovního poměru do výzkumných ústavů a na vysoké školy. Právě o postdoktorandy se však vede boj, nebot' další pokrok ve vědě a technologiích závisí na jejich kvalitě. $\mathrm{V}$ celosvětovém měřítku spolu soutěží národní systémy práce s postdoktorandy a ty systémy, které mohou postdoktorandům nabídnout lepší podmínky, způsobují „odliv mozků“. U přírodních a technických věd to doložil v dříve publikované přehledové studii např. Moguérou (2005).

Zmíněná konference v Berlíně, jíž se zúčastnili zástupci přírodních i humanitních věd, dospěla $\mathrm{k}$ pěti závěrưm: 
(1) Je třeba celosvětověřešit rozpor mezi vzrůstajícími počty postdoktorandů a omezeným počtem stálých míst, jichž je možno dosáhnout tradičním kariérním postupem.

(2) Je třeba vytvářet více pracovních míst ve vědecko-výzkumných ústavech a na vysokých školách pro postdoktorandy.

(3) Je třeba připravit a zavést diferencované typy postdoktorandského vzdělávání a výcviku. Jeden bude směřovat absolventy ke kariéře špičkového vědce, druhý ke kariéře špičkového vysokoškolského učitele.

(4) Je třeba odstraňovat překážky, které brání mobilitě postdoktorandů. Ti musí poznat, jak se odborně pracuje $\mathrm{v}$ jiných institucích dané země, ale i v jiných zemích.

(5) Na národní úrovni je třeba vytvářet atraktivní pracovní prostředí pro vynikající mladé výzkumné pracovníky a pro vynikající mladé vysokoškolské učitele (Alexander von Humboldt-Foundation, 2007).

$\mathrm{Z}$ toho, co bylo uvedeno, je zřejmé, že je třeba se systematičtěji věnovat postdoktorandskému vzdělávání a výcviku. Zahraniční zkušenosti mohou být pro nás inspirací, jak postupovat při výzkumu této důležité životní etapy badatelů a vysokoškolských učitelů, a současně i impulsem, jaké postupy se na různých úrovních dají použít. Bude to ku prospěchu jak samotných postdoktorandů, tak výzkumných ústavů a vysokých škol.

\section{Literatura}

Åkerlind, G. S. (2005). Postdoctoral researchers: Roles, functions and career prospects. Higher Education Research and Development, 24(1), 21-40.

Åkerlind, G. S. (2009). Postdoctoral research positions as preparation for an academic career. International Journal of Researcher Development, 1(1), 84-96.

Alexander von Humboldt-Foundation (2007). Postdoctoral career paths: Observations and recommendations. Berlin: Forum on the Internationalization of Sciences and Humanities. Dostupné z http://www.humboldt-foundation.de/web/iab-forum-2007recommendations.html

APA (2007). Guidelines for education and training at the doctoral and postdoctoral levels in consulting psychology/organizational consulting psychology. American Psychologist, 62 (9), 980-992.

Aschwanden, C. (2006). Professionalizing the postdoctoral experience. Cell, 124(3), 445-447.

Biedermann, L. B., Cruz-Campa, J. L., \& Ekoto, I., et al. (2012). Postdoctoral program guidelines. Albuquerque: Sandia National Laboratories.

Covington, M. V. (2000). Goal theory, motivation, and school achievement: An integrative review. Annual Review of Psychology, 51, 171-200. 
Cozzens, S. E., Healey, P., \& Rip, A., et al. (1990). The research system in transition. Dordrecht: Kluwer.

Dalton, G. W., Thompson, P. H., \& Price, R. L. (1977). The four stages of professional careers: Change, continuity and context. Organization Dynamic, 6(1), 19-42.

Davies, G. (2009). Improving the postdoctoral experience: An empirical approach. In R. Freeman \& D. Goroff (Eds.), Science and engineering careers in United States: An analysis of markets and employment (s. 99-130). Chicago: University of Chicago Press.

Gennaro, S., Deatrick, J. A., \& Dobal, M. T. (2007). An alternative model for postdoctoral education of nurses engaged in research with potentially vulnerable populations. Nursing Outlook, 55(6), 275-281.

Ježek, S., \& Mareš, J. (2012). Kvalita doktorského studia na UK Praha z pohledu absolventů (šetření $v$ letech 2005, 2007, 2011). Referát na zasedání vědecké rady Univerzity Karlovy, 26. 1. 2012.

Lauder, G., \& Gläser, J. (2008). From apprentice to colleague: The metamorphosis of early career researchers. Higher Education, 55(3), 387-406.

Marsh, H. W., \& Parker, J. (1984). Determinants of student self-concept: Is it better to be a relative large fish in a small pond even if you don't learn to swim as well? Journal of Personality and Social Psychology, 47(1), 213-231.

Marsh, H. W., Rowe, K., \& Martin, A. (2002). PhD students' evaluations of research supervision: Issues, complexities and challenges in nationwide Australian experiment in benchmarking universities. Journal of Higher Education, 73(3), 313-348.

Marsh, H. W., Seaton, M., \& Trautwein, U., et al. (2008). The big-fish-little-pond-effect stands up o critical scrutiny: Implications for theory, methodology, and future research. Educational Psychology Review, 20(3), 319-350.

Maxwell, J. M. (2009). Contesting the culture of the doctoral degree: Candidates' experiences of three doctoral degrees in the School of Education RMIT University. Melbourne: School of Education RMIT University.

Moguérou, P. (2005). Doctoral and postdoctoral education in science and engineering: Europe in the international competition. European Journal of Education, 40(4), 367-392.

MŠMT (2011). Program postdoktorandi. Dostupné z http://www.msmt.cz/strukturalni-fondy/ program-postdoktorandi

Muniyappa, K. (2007). The role of postdoctoral training for careers in research and higher education. Current Science, 92(4), 450-454.

National Postdoctoral Association (2013). Dostupné z http://www.nationalpostdoc.org/index. $\mathrm{php} /$ policy-22/what-is-a-postdoc

Nerad, M., \& Cerny, J. (2002). Postdoctoral appointments and employment patterns of science and engineering doctoral recipients ten-plus years after Ph.D. completion: Selected results from the "Ph.D.s - ten years later" study. The Council of Graduate Schools Communicator, 35(7), 1-2 a 10-11.

Neumannová, H., \& Nejedlová, D. (2009). Šance absolventů doktorského studia na pracovním trhu $v$ Euroregionu Nisa. Liberec: Technická univerzita v Liberci.

Neusar, A., \& Charvát, M., et al. (2012). PhD existence v oboru psychologie v České republice a na Slovensku. Olomouc: Filozofická fakulta Univerzity Palackého.

Scaffidi, A. K., \& Berman, J. E. (2011). A positive postdoctoral experience is related to quality supervision and career mentoring, collaborations, networking and a nurturing research environment. Higher Education, 62(6), 685-698. 
Seznam recenzovaných neimpaktovaných periodik vydávaných v České republice. (2010). Praha. Rada vlády pro výzkum, vývoj a inovace. Dostupné z http://www.vyzkum.cz/FrontClanek. aspx?idsekce $=495942$

Thole, W., Faulstich-Wieland, H., \& Horn, K. P., et al. (Eds.) (2012). Datenreport Erziehungswissenschaft. Leverkusen-Opladen: Verlag Budrich.

Tillmann, K. J., Rauschenbach, T., \& Tippelt, R., et al. (Eds.). (2008). Erziehungswissenschaft. Leverkusen-Opladen: Verlag Budrich.

Thomson, J., Pearson, M., \& Åkerlind, G., et al. (2001). Postdoctoral training and employment outcomes. Canberra: EIP, Higher Education Division, Department of Employment, Education, Training and Youth Affairs.

Výroční zpráva o činnosti za rok 2011. (2012). Brno: Masarykova univerzita.

Výroční zpráva o činnosti za rok 2011. (2012). Olomouc: Univerzita Palackého.

Výroční zpráva o činnosti za rok 2011. (2012). Praha: Univerzita Karlova.

\section{Autor}

Prof. PhDr. Jiřri Mareš, CSc., Univerzita Karlova v Praze, Lékařská fakulta v Hradci Králové, Ústav sociálního lékařství, Šimkova 870, 50038 Hradec Králové, e-mail: mares@lfhk.cuni.cz

\section{The invisible group, or what to do with postdocs?}

Abstract: The paper aims 1. to draw attention to the situation in the Czech Republic, where universities „produce“ tens of PhD graduates every year and are little interested in their future; 2 . to clarify the term „postdoc" and introduce research studies that deal with this group of university graduates; 3 . to present some information about PhD graduates in the field of educational sciences in the Czech Republic; 4 . to discuss the Czech context that influences the employment of postdocs; 5. to summarize findings from abroad about systematic work with postdocs. In the first part we describe the current situation in the Czech Republic and abroad. In the second part we introduce the research study about the number of successful graduates from educational sciences doctoral programmes. The third part focuses on the Czech context that influences the employment of postdocs. The fourth part summarizes the experience from other countries considering systematic work with postdocs. In our research study we found that 549 people successfully completed a doctoral programme in educational sciences in 1999-2011. Systematic work with postdocs has been initiated at three universities (Charles University, Masaryk University, Palackého University) but is at its outset. From the above mentioned it follows that in the Czech context it will be necessary to monitor where postdocs work, to what degree they focus on research, and what their career path looks like. Besides this, it will be crucial (based on experience from abroad) to devise a system that will allow postdocs to follow various paths when it comes to broadening their knowledge and improving their skills.

Keywords: doctoral education, education, postdoc, career, educational research 